\title{
Kvalitetssikring, ikke forskning
}

\author{
Prosessen frem mot publikasjon av vår artikkel som trykkes i dette nummer av Tidsskriftet har vært kompli- \\ sert. Tidsskriftet har gitt sin versjon av prosessen på lederplass, og har gitt oss anledning til å kommentere \\ den sett fra vår side.
}

Først og fremst vil vi presisere at vi i forhold til denne pasientgruppen er behandlere og ikke forskere. Metoden med transkateter aortaventilimplantasjon oppfatter vi som en videreutvikling av allerede etablerte kateterbaserte teknikker som vi ved Universitetssykehuset Nord-Norge var tidlig ute med å innføre. Vi innførte stentgraftbehandling for sykdom i abdominal- og torakalaorta og i aortabuen i hhv. 1997, 1999 og 2005.

På samme måte som ved innføringen av kateterbasert behandling i aorta har vi også ved etableringen av transkateter aortaventilimplantasjon-programmet prospektivt fulgt disse pasientene nøye med tanke på utilsiktede hendelser, komplikasjoner, behandlingseffekt og livskvalitet. Dette oppfatter vi ikke som forskning, men som kvalitetssikring ved innføring av ny teknologi. Den aktuelle publikasjonen (1) er derfor etter vår oppfatning å betrakte som vår forste behandlingskohort snarere enn en studie.

Følgelig er den ikke fremleggingspliktig for regional etisk komité. For øvrig var følgende forhold medvirkende til vår beslutning:
- Da vi startet programmet var mer enn 2000 klaffer allerede implantert i Europa og det forelå et titalls publikasjoner som viste at metoden var lovende og at den ga rask symptombedring hos en pasientgruppe som i praksis sto uten behandlingstilbud (2).

- Våre naboland hadde allerede startet sine programmer på lik linje med de fleste vesteuropeiske land.

- Vi var uenig i konklusjonen til Nasjonalt råd for kvalitet og prioritering $i$ helsetjenesten om at behandlingen var eksperimentell og ikke skulle tilbys norske pasienter på det daværende tidspunkt. Nasjonalt råd har siden (arkivnr. 09/64) konkludert med at eksisterende definisjoner på eksperimentell, utprøvende og etablert behandling ikke tydelig synliggjør overgangen mellom forskning og behandling.

En randomiserte studie (3) har senere konkludert med at transkateter aortaventilimplantasjon bør være den nye standardbehandlingen for pasienter med aortastenose som ikke er egnede kandidater for åpen kirurgi.

\section{Rolf Busund}

rolf.busund@unn.no

Hjerte-, lunge- og karkirurgisk avdeling

Terje K. Steigen

Hjertemedisinsk avdeling

Torvind Næsheim

Anestesiavdelingen

Børge Schive

Hjertemedisinsk avdeling

Universitetssykehuset Nord-Norge 9038 Tromsø

Oppgitte interessekonflikter: Ingen

\section{Litteratur}

1. Steigen TK, Schive B, Næsheim T et al. Transkateter aortaventilimplantasjon ved aortastenose. Tidsskr Nor Legeforen 2011; 131: 343-8.

2. Lauvrak V, Ørjasæter Elvsaas I et al. Kateterbasert implantasjon av aortaklaffer. Metodevarsel nummer 3. Oslo: Kunnskapssenteret, 2008.

3. Leon MB, Smith CR, Mack M et al. Transcatheter aortic-valve implantation for aortic stenosis in patients who cannot undergo surgery. N Engl J Med 2010; 363: 1597-607.

Mottatt 19.1.2011, godkjent 20.01.2011. Medisinsk redaktør Anne Kveim Lie. 